\title{
Vliv dostupnosti kyslíku a dusičnanů na cyklus fosforu v sedimentu - príklad nádrže Vranov
} JIŘí JAN, JAKUB BOROVEC, DANIEL PETRÁŠ, NANA OSAFO, IVA TOMKOVÁ, TOMÁŠ HUBÁČEK

Klíčová slova: sediment - kyslík - fosfor - železo - eutrofizace

\section{SOUHRN}

Přispěvek se zabývá vlivem sedimentu přitokové části nádrže Vranov na přísun fosforu (P) do vodního sloupce nádrže za různých podmínek dostupnosti tzv. terminálních akceptorů elektronů, zejména rozpuštěného $\mathrm{O}_{2}$ a $\mathrm{NO}_{3}$. Př́tokové části eutrofních nádrží jsou typické vysokou primární produkcí fytoplanktonu a následnou sedimentací organického materiálu. Mikrobiální procesy spotřebovávají při jeho mineralizaci akceptory elektronů a v závislosti na míchání vodního sloupce může docházet k výkyvům jejich dostupnosti. Pro určení jejich vlivu byly kóry sedimentů inkubovány pět týdnů ve třech různých variantách, které simulovaly: i) anoxický vodní sloupec se současným vyčerpáním $\mathrm{NO}_{3}$; ii) saturovaný vodní sloupec s rozpuštěným $\mathrm{O}_{2}$ a iii) saturovaný vodní sloupec $\mathrm{O}_{2}$ a zvýšené koncentrace $\mathrm{NO}_{3}$. Pomocí sledování změn koncentrací ve vodě nad sedimentem, průběžné analýzy pórové vody a změn ve složení částic a zastoupení forem a množství P na začátku a konci experimentu jsme zjistili míru uvolňování $P$ a určili vliv železa ( Fe) v tomto sedimentu.

\section{ÚVOD}

Ke zhoršování kvality vody (myšleny zejména projevy eutrofizace a jevy s ní spojené) dochází především vnosem fosforu (P) do nádrže př́tokem. Na tento negativní proces však mají často aditivní vliv také sedimenty, ze kterých se P bud’ může uvolňovat, nebo jej sedimenty málo zadržují. Sedimenty $v$ nádržích tak funguji jako dynamický zásobník látek, do kterého se současně ukládají a z něj i uvolňují v závislosti na okolních podmínkách a biogeochemických procesech. Výměna látek mezi vodou a sedimenty je rízena zejména teplotou vody, prísunem látek (koncentrace a formy) z povodí, průtoky, disturbancemi sedimentů (povodňové epizody, manipulace s hladinou, ryby), prítomností vazebných prvků (železo, hliník, mangan, organická hmota) a dalšími vlivy.

Přítokové části nádrží obvykle zachycují největší objemy sedimentů, jejich množství a kvalita se však liší nejen v podélném, ale i v příčném profilu nádrže $\checkmark$ závislosti na hydraulických vlastnostech vodního sloupce. $V$ prítokových zónách rovněž dochází k nejmasovějšímu rozvoji řas a sinic, jejichž biomasa postupně sedimentuje z vodního sloupce. Pokud se tak děje ještě v zóně úplného míchání vodního sloupce, zpravidla nedochází ke kumulaci sestonu na dně, ale $k$ jeho rychlému rozkladu. $V$ prípadě, kdy míchaná část vodního sloupce již nedosahuje ke dnu, dochází ke vzniku lokálních bezkyslíkatých zón, k nedostatečnému rozkladu sedimentovaných částic a k ukládání nestabilizovaného, živinami bohatého sedimentu, schopného efektivně uvolňovat živiny zpět do vodního sloupce [1]. Zóny dna těchto částí nádrže se tak často mění ve smyslu dostupnosti kyslíku $\left(\mathrm{O}_{2}\right)$ a prípadně dusičnanů $\left(\mathrm{NO}_{3}{ }^{-}\right)$, které mají zásadní vliv na metabolismus bakterií a určují chování sedimentu.
S rostoucí hloubkou nádrže klesá vliv sedimentu jako zdroje živin k rozvoji fytoplanktonu ve vodním sloupci, nebot P uvolňovaný ze sedimentu zůstává $\checkmark$ hypolimnetické části vodního sloupce, tedy pod produkční zónou fytoplanktonu. Tyto přítokové části nádrže na rozhraní míchaného/nemíchaného vodního sloupce jsou tak nejdynamičtější a mají největší vliv na trofii celé nádrže.

Sedimenty obsahují nejen částice, ale také pórovou vodu, která funguje jako transportní spojovatel mezi sedimenty a vodou nad sedimenty. Prostřednictvím ní se do sedimentu dostávají z vodního sloupce látky, které jsou zde $v$ nízkých koncentracích a jsou spotřebovávány (zejména rozpuštěný $\mathrm{O}_{2^{\prime}}$ $\mathrm{NO}_{3}$; $\mathrm{SO}_{4}^{2-}$ ). Naopak ze sedimentu jsou transportovány látky, které se vlivem chemických a mikrobiálních procesů na částicích rozpouštějí do pórové vody (napr. $\mathrm{P} \mathrm{NH}_{4}^{+}, \mathrm{CO}_{2}$ a další).

Rozpuštěné látky $v$ pórové vodě, včetně $\mathrm{P}$, se dostávají ze sedimentu do vody v nádrži bud' přímou difúzí, nebo rychleji díky rozrušování celého sedimentu bioturbací bezobratlých živočichů (např. larvy pakomárů) a ryb, produkcí a následným vybubláním plynů nebo resuspenzí sedimentu díky pohybům vody [2]. Biogeochemické změny částic pak závisejí na parametrech, jako je teplota, která dále ovlivňuje rychlosti chemických a zvláště mikrobiálních aktivit, dostupnost tzv. akceptorů elektronů $\mathrm{O}_{2}, \mathrm{NO}_{3}^{-} \mathrm{SO}_{4}{ }^{2-}$ a následně oxidačně-redukční potenciál (Eh) a pH, formy organických látek, a dále pak sorpčně desorpční rovnováhy. Akceptory elektronů jsou důležité pro proces oxidace organických sloučenin bakteriemi. Pokud je sediment anoxický a jsou vyčerpány výše zmíněné akceptory (zejména $\mathrm{O}_{2}$ a $\mathrm{NO}_{3}^{-}$), dochází k redukci sloučenin $\mathrm{Mn}^{1 \mathrm{~V}}$ na $\mathrm{Mn}$ " a zejména více zastoupeného Fe" na Fe", které se tak rozpouštějí do pórové vody. Felll sloučeniny a zejména jeho (hydr)oxidy jsou hlavním vazebným partnerem pro $P$, proto dochází k současnému rozpouštění $P$ do pórové vody. Pokud obsahuje pórová voda vyšší koncentrace rozpuštěného Fe, můžeme s jistotou říci, že dochází k redukčnímu rozpouštění Fe (hydr)oxidů a současně $k$ preměně $P$ z pevné formy do rozpuštěné a zpř́stupnění tohoto $P$ pro přechod do vodního sloupce. Sedimenty s vysokými koncentracemi $P$ $\checkmark$ pórové vodě mají tak vysoký eutrofizační potenciál.

$\checkmark$ tomto přispěvku bude ukázán způsob zjištění potenciálního vlivu sedimentu z př́tokové části nádrže Vranov na kvalitu vody v nádrži za př́tomnosti Či nepř́tomnosti kyslíku, dostupnosti $\mathrm{NO}_{3}{ }^{-}$a vysvětlen mechanismus uvolňování P ze sedimentu. 


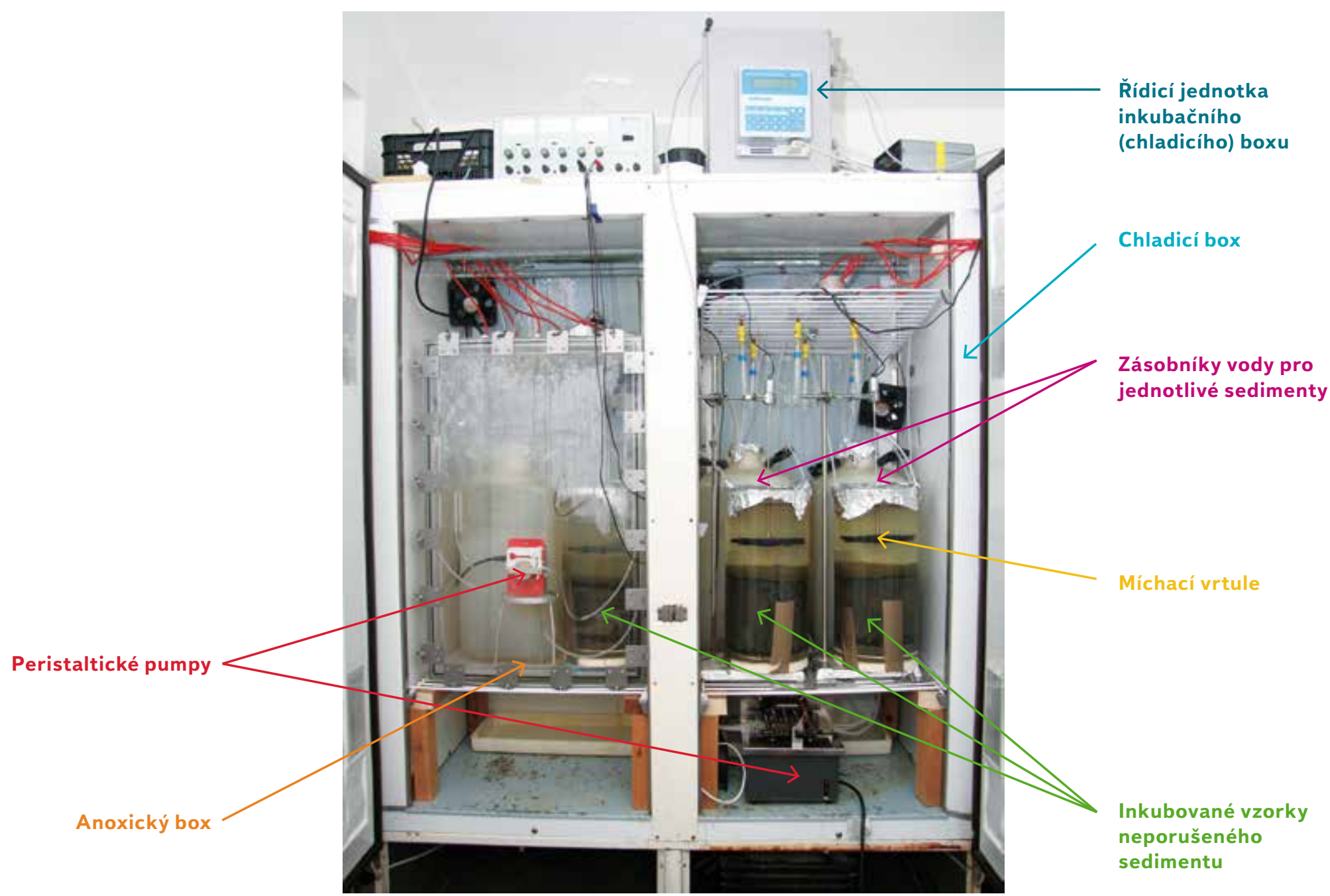

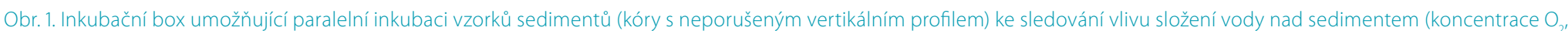

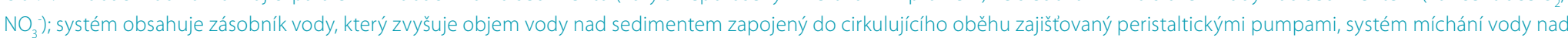
sedimentem (míchací vrtule s jednotnou rychlostí míchání) a box umožňující simulaci bezkyslíkatých podmínek (plexisklová komora s průtokem čistého plynného $\mathrm{N}_{2}$ )

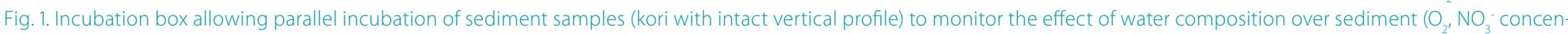

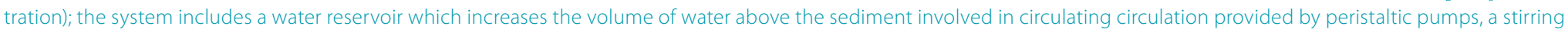

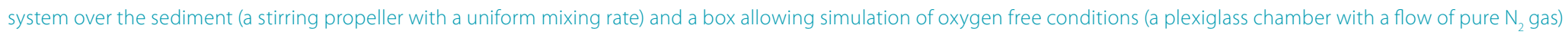

\section{MATERIÁL A METODY}

\section{Odběr sedimentů}

Studovaný sediment byl odebrán na nádrži Vranov v lokalitě mezi "Farářkou“ $\mathrm{a}$ „M. Loučky" 23. 8. 2016. V době a místě odběru byla koncentrace $\mathrm{O}_{2} 4 \mathrm{mg} \cdot \mathrm{l}^{-1}$ $\checkmark$ hloubce $0,5 \mathrm{~m}$ nade dnem. Celkem čtyři paralelní vzorky sedimentů z identické lokality byly odebrány inovovaným gravitačním odběrákem do plexisklových trubic o průměru $20 \mathrm{~cm}$ a výšce $40 \mathrm{~cm}$. Takto odebrané vzorky umožnily zachování svrchní vrstvy sedimentu s neporušeným vertikálním profilem, který odpovídal stavu sedimentů v nádrži (vzorky z průběhu inkubace viz obr. 1). Současně byla z vodního sloupce nade dnem odebrána voda do 25 I barelů, která sloužila následně během inkubačního sledování jako zásobárna vody. Tento objem (společně s vodou nad sedimentem v odběrové trubici) odpovídal výšce vodního sloupce $1 \mathrm{~m}$ nad plochu sedimentu vzorků v trubicích.

\section{Inkubace kórů a sledování změn koncentrací ve vodě nad sedimentem}

Kóry sedimentů byly umístěny do inkubačního boxu temperovaného na $12{ }^{\circ} \mathrm{C}$, napojeny na systém kontinuální výměny vody mezi vodou nad sedimentem v kóru a zásobní vodou v barelu. Nad sediment byly následně umístěny míchací vrtule simulující pomalé proudění vody nad sedimentem (obr. 1). Byly simulovány tři varianty podmínek ve vodním sloupci:

A. vodní sloupec bez prítomnosti rozpuštěného $\mathrm{O}_{2}$ a $\mathrm{NO}_{3}^{-}$(sediment byl umístěn $\checkmark$ uzavřeném plexisklovém boxu, do kterého neustále proudil čistý plynný $\mathrm{N}_{2^{\prime}}$ který současně probublával také barel s vodou),

B. sediment s neustálým prísunem $\mathrm{O}_{2}$ ve vodním sloupci (otevrená trubice se sedimentem a vodou, barel navíc probubláván atmosférickým vzduchem), 
C. sediment s prísunem rozpuštěného $\mathrm{O}_{2}$ a za zvýšené koncentrace $\mathrm{NO}_{3}^{-}$(bublání jako $v$ předešlé variantě, navíc přidán do barelu rozpuštěný $\mathrm{NaNO}_{3^{\prime}}$ jehož prídavek odpovídal celkovému prísunu $\left.\mathrm{NO}_{3}{ }^{-} \mathrm{N} 4 \mathrm{mg} \cdot \cdot^{-1}\right)$. Sediment byl inkubován po celkovou dobu 35 dní, během níž byl třikrát týdně odebírán vzorek vody pro sledování změn koncentrací rozpuštěných iontů a prvků.

\section{Analýza pórové vody}

Každý týden byl monitorován ve všech variantách vývoj koncentrací rozpuštěných látek v pórové vodě vertikálního profilu sedimentu. Pro vzorkování pórové vody byla použita upravená technika DET (Diffusive Equilibrium in Thin Film). Minipeeper s aktivní gelovou částí o celkové délce $9 \mathrm{~cm}$ byl zasunut do sedimentu a exponován zde 24 hodin. Tato málo invazivní metoda a velký průměr kórů nám umožnila vzorkování pórové vody ve stejném kóru, pouze na vždy jiném místě. Pro informace ohledně této techniky viz [3, 4].

\section{Formy P v sedimentu a sledování změn složení částic}

Pro sledování změn složení částic sedimentů vyvolaných vývojem sedimentu za různých podmínek inkubace byl vzorek sedimentu analyzován pomocí frakcionace P. Jeden kór byl $v$ době začátku inkubace (použit čtvrtý neinkubovaný replikát) rozřezán ve vertikálním profilu do vrstev o výšce $1 \mathrm{~cm}$. V těchto vrstvách byl stanoven obsah $\left(105^{\circ} \mathrm{C}, 2\right.$ hod) a ztráta žíháním, která odpovídá obsahu organické složky v částicích sedimentu $\left(550^{\circ} \mathrm{C}, 2\right.$ hod). Vzorky z jednotlivých vrstev byly analyzovány pomocí frakcionace podle Jan a kol. [5], ke stanovení forem $\mathrm{P}$ a jeho vazebných partnerů (tabulka 1). Stejně byly rozřezány a zanalyzovány tři inkubované kóry po ukončení inkubačního sledování, ke stanovení změn složení částic způsobených různými podmínkami ve „vodním sloupci nad sedimentem“.

Tabulka 1. Označeníjednotlivých extrahovaných frakcía popis nejdůležitějších forem P, Mn, Fe a Al extrahovaných v jednotlivých extrakčnich krocich

Table 1. Labeling of individual extracted fractions and description of the most important forms of P, Mn, Fe and Al extracted in individual extraction steps

\section{Krok Frakce Extrahovaná forma}

\begin{tabular}{lll}
\hline 1. & $\mathrm{H}_{2} \mathrm{O}$ & rozpuštěný a volně adsorbovaný P \\
\hline 2. & BD-I & $\begin{array}{l}\text { nejostostupnějši (hydr)oxidy Mn a Fe pro bakteriální } \\
\text { a chemickou redukci a P na těchto nejvíce sorpčně } \\
\text { aktivních formách navázaný }\end{array}$ \\
\hline 3. & BD-II & $\begin{array}{l}\text { hůře redukovatelné (hydr)oxidy Fe a Mn } \\
\text { s navázaným P }\end{array}$ \\
\hline
\end{tabular}

\begin{tabular}{lll}
\hline 4. & $\mathrm{NaOH}-\mathrm{l}$ & $\begin{array}{l}\text { amorfní a vysoce sorpčně aktivní (hydr)oxidy Al } \\
\text { s navázaným P, organické formy } P\end{array}$ \\
\hline 5. & $\mathrm{NaOH}-\|$ & $\begin{array}{l}\text { krystalické (hydr)oxidy Al s navázaným P, stabilnější } \\
\text { formy organického } P\end{array}$ \\
\hline 6. & $\mathrm{HCl}$ & $\begin{array}{l}\text { apatity a } \mathrm{CaCO}_{3} \text { s adsorbovaným P } \\
\text { Fe ve formách sulfidů, uhličitanů a kremičitanů }\end{array}$ \\
\hline 7. & zbytek & nedostupné formy s extrakčními činidly
\end{tabular}

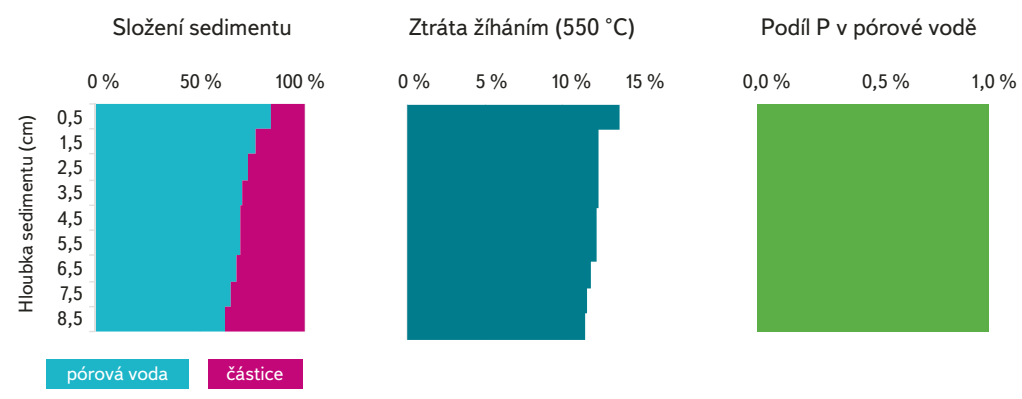

Obr. 2. Základní charakteristika složení studovaného sedimentu z přítokové části nádrže Vranov; vlevo - procentuálně vyjádřené hmotnostní zastoupení pórové vody a částic, uprostřed - ztráta žíháním částic při $550{ }^{\circ} \mathrm{C}$, vpravo - procentuální vyjádření obsahu P v pórové vodě vưči celkovému obsahu P v jednotlivých vrstvách sedimentu

Fig. 2. Basic characteristics of the composition of the studied sediment from the inlet part of the Vranov reservoir; left - percentage weight of porous water and particles, middle - loss of particle annealing at $550^{\circ} \mathrm{C}$, right - percentage of content of $\mathrm{P}$ in pore water to total $\mathrm{P}$ content in individual layers of sediment

\section{VÝSLEDKY A DISKUSE}

\section{Obecné vlastnosti sedimentu}

Základní parametry sedimentu před zahájením inkubací jsou vyobrazeny na obr. 2. Sediment obsahoval $86 \%$ vody v nejsvrchnější vrstvě $0-1 \mathrm{~cm}$ a postupně klesal až na $57 \%$ ve vrstvě $8-9 \mathrm{~cm}$. Částice sedimentu, které tvořily zbytek sedimentu, pak obsahovaly príbližně $14 \%$ organické složky (stanoveno jako ztráta žíháním při $550^{\circ} \mathrm{C}$ ) a klesaly s hloubkou sedimentu na $12 \%$ ve spodní sledované vrstvě. Zjevně vyšší zastoupení organické složky v nejsvrchnější vrstvě je způsoben nasedimentovanou organickou hmotou $v$ průběhu produkční sezony fytoplanktonu. Pokud se pak zaměríme na poměr mezi obsahem $P$ rozpuštěného $v$ pórové vodě a celkovým obsahem $P$ v jednotlivých vrstvách (rozpuštěný + částicový), vidíme, že pórová voda na počátku inkubace obsahovala pouze méně než $1 \%$ z celkového množství $P \vee$ sedimentu a klesala $s$ hloubkou až na 0,5 \%. Ačkoli se zdá toto procento velice nízké, hraje pórová voda významnou roli nejenom z hlediska množství P v ní, ale také jako transportní médium mezi sedimentem a vodou nad ním viz dále.

\section{Změny koncentrací ve vodě nad sedimentem}

Výsledky monitoringu vody nad sedimentem v průběhu inkubačního pokusu ukázaly výrazný vliv podmínek během inkubace (obr.3). Zatímco sediment inkubovaný za anoxických podmínek vody nad sedimentem (anox) vykazoval kontinuální uvolňování $P$ ze sedimentu, u obou oxických variant, jak bez př́idavku $\mathrm{NO}_{3}^{-}$(ox), tak i s prídavkem $\mathrm{NO}_{3}^{-}\left(\mathrm{NO}_{3}\right)$, k uvolňování $\mathrm{P}$ ze sedimentu nedocházelo. Sediment o ploše $1 \mathrm{~m}^{2}$ tak $v$ anoxii uvolnil celkem $435 \mathrm{mg} P$ během 35 dní inkubace, vyjádřeno na koncentrace, zatímco počáteční stav byl $70 \mathrm{mg} \cdot \mathrm{m}^{3} \mathrm{P}$, koncový stav $505 \mathrm{mg} \cdot \mathrm{m}^{3} \mathrm{P}$, což znamená, že $1 \mathrm{~m}^{2}$ sedimentu každý den obohatil 1 I vody ve vodním sloupci o výšce 1 m o 12,4 Mg P. Toto anoxické uvolňování $P$ nebylo doprovázeno uvolňováním Fe do vodního sloupce, jak je vidět na obr.3, a koncentrace rozpuštěného Fe zůstala na stabilní nízké koncentraci. V oxických variantách došlo k dalšímu poklesu koncentrace Fe, tedy k vysrážení z vodního sloupce do částic. Redukční rozpouštění pak bylo patrné u dalšího redox labilního prvku, manganu (Mn). Z těchto výsledků se může zdát, že za uvolňování není zodpovědné rozpouštění železitých sloučenin s $P$, opak je však pravdou, jak potvrzuji výsledky analýzy pórové vody a frakcionace. 


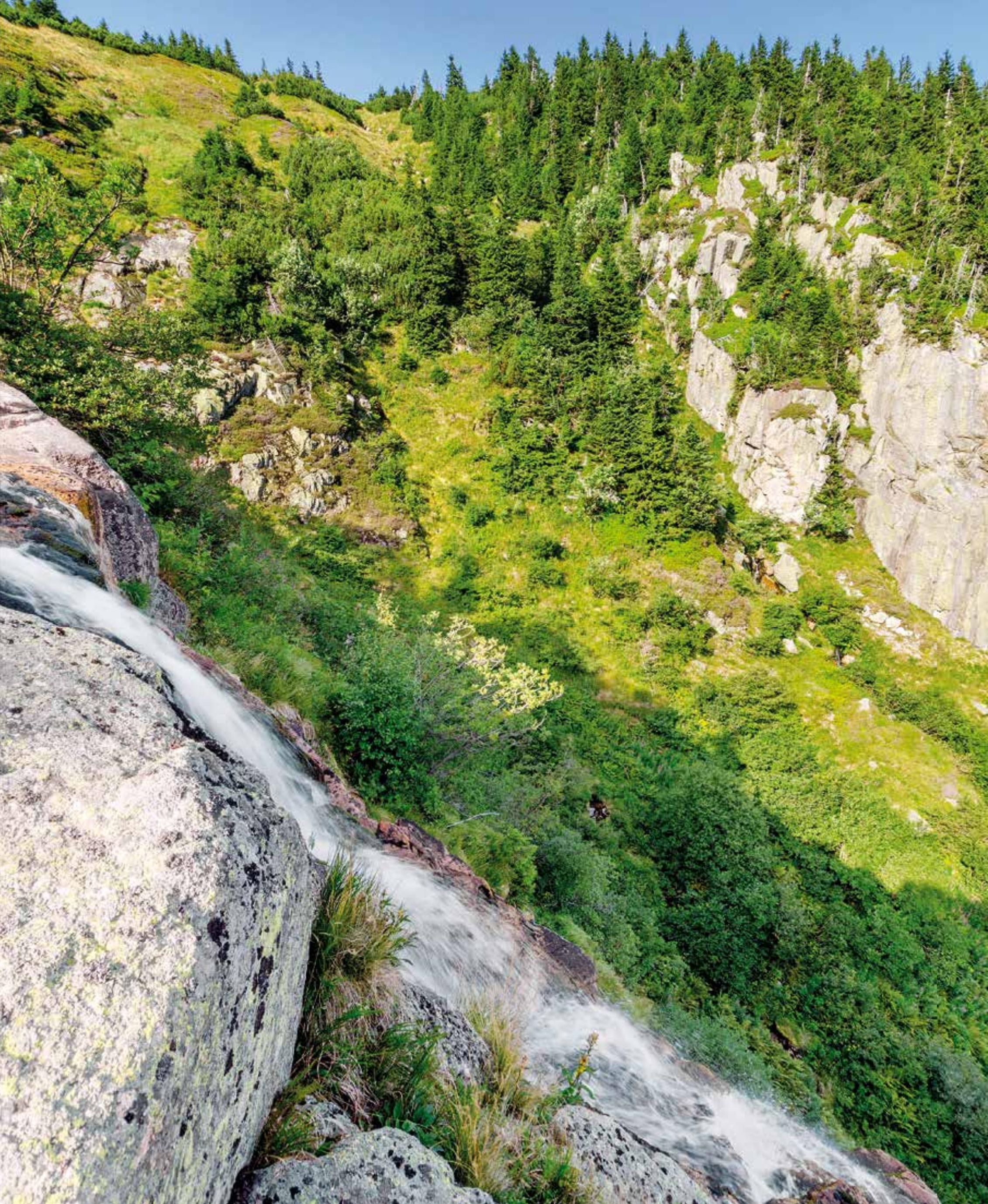




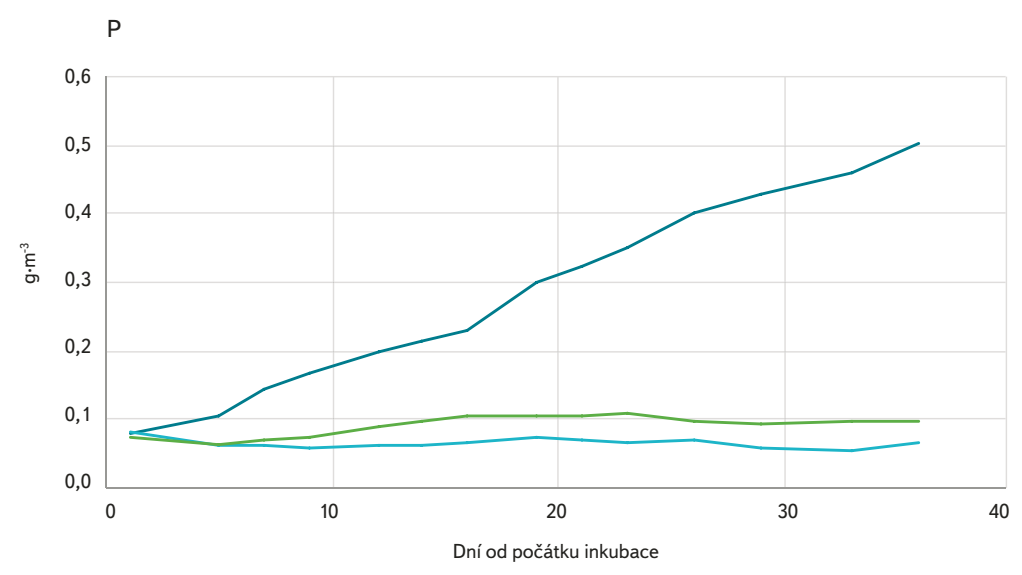

$\mathrm{Fe}$
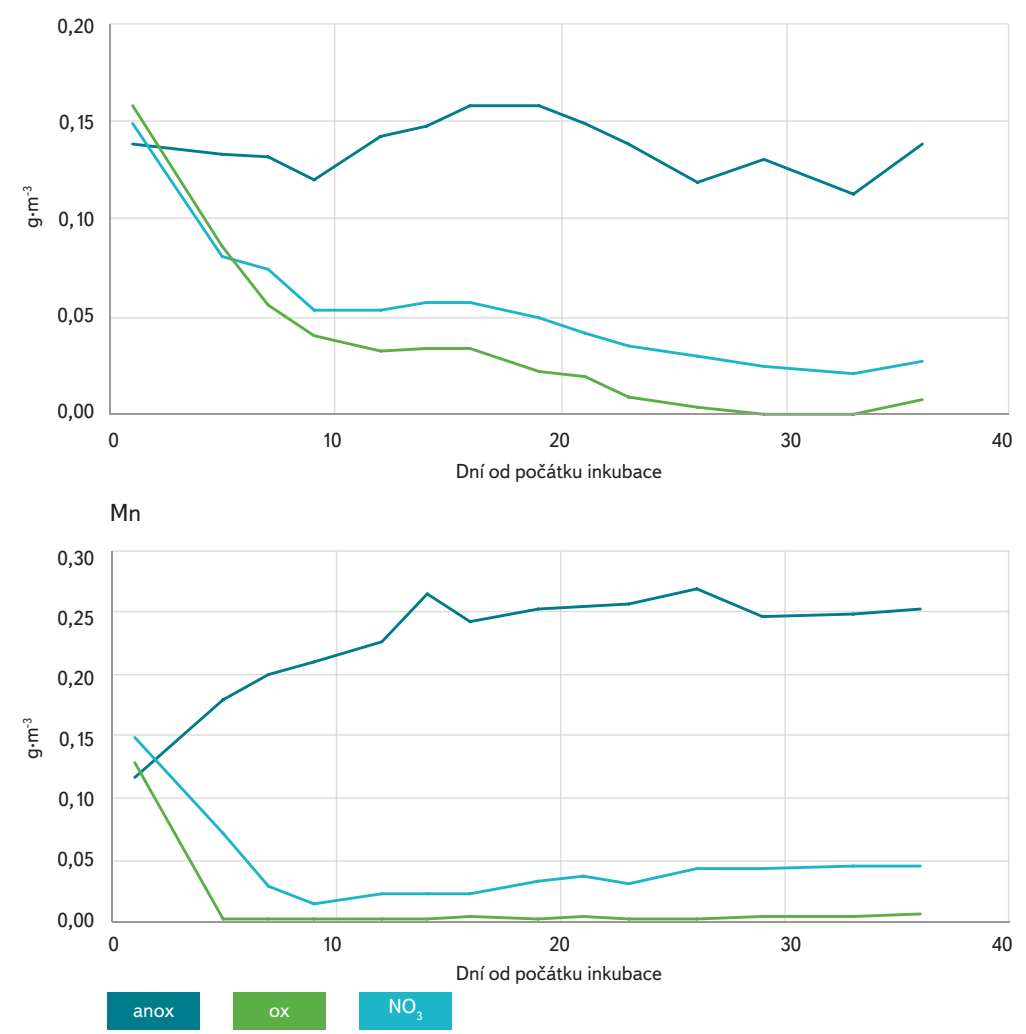

Obr. 3. Průběh změn koncentrací $P$, Fe a $M n$ ve vodě nad sedimentem o ploše $1 m^{2}$ a výšce vodního sloupce $1 \mathrm{~m}$ vyjádřená v jednotkách $\mathrm{g} \cdot \mathrm{m}^{-3}$

Fig. 3. The course of variations in P, Fe and Mn concentrations in water above the sediment area of $1 \mathrm{~m}^{2}$ and the height of the water column $1 \mathrm{~m}$, expressed in units of $\mathrm{g} \cdot \mathrm{m}^{-3}$

\section{Analýza pórové vody}

Z analýz pórových vod (obr. 4) je patrné, že na počátku inkubace (den 0) byl vysoký obsah celkového rozpuštěného $P$ v jednotlivých vrstvách sedimentu včetně nejsvrchnější vrstvy $0-0,5 \mathrm{~cm}\left(c=3,3 \pm 0,5 \mathrm{mg} \cdot \cdot^{-1} \mathrm{P}\right)$. Tato koncentrace byla téměř $50 \times$ vyšší oproti koncentraci $P$ ve vodním sloupci na počátku inkubace (70 $\left.\mu \mathrm{g} \cdot \mathrm{l}^{-1} \mathrm{P}\right)$. Díky tomuto vysokému koncentračnímu gradientu P na rozhraní sediment/voda docházelo $\mathrm{k}$ difuznímu transportu $\mathrm{P}$ pórovou vodou ven ze sedimentu. Jak je pak patrné z dalších dvou sledování po 14 a 28 dnech, vysoké množství $P$ je stále ve svrchních vrstvách prítomno. Tento obsah $\mathrm{P} \vee$ pórové vodě je tedy výsledkem dvou procesů: i) transportem $P$ ven ze sedimentu (viz akumulace $P$ ve vodním sloupci) a generováním rozpuštěného $P$ uvnitř sedimentu díky preměně/rozpouštění částic obsahujících $P$, jak bude ukázáno dále. $\vee$ prípadě oxické varianty (ox) v průběhu inkubace docházelo $k$ výraznému poklesu $P$ ve vrstvě $0-3 \mathrm{~cm}$ a zejména nejvíce ve svrchních vrstvách pod povrchem sedimentu. Tento pokles byl ještě výraznější u inkubovaného sedimentu s vyšší koncentrací $\mathrm{NO}_{3}{ }^{-}$ve vodním sloupci $\left(\mathrm{NO}_{3}\right)$. Nízký obsah P tak zaprríčinil, že sedimenty P neuvolňovaly.

Pokud se zaměříme na profily rozpuštěného Fe v pórové vodě (obr. 4), je patrné, že mají stejný průběh, jako u P. Znamená to, že v sedimentu nedocházelo $\mathrm{k}$ rozpouštění železitých sloučenin $\mathrm{S} P$, naopak díky prítomnosti oxické vody nade dnem docházelo k postupnému „prooxidovávání" svrchní vrstvy sedimentu a ke srážení nových Fe P sloučenin. Ke stejnému efektu docházelo, pokud byly prítomny ionty $\mathrm{NO}_{3}{ }^{-} \mathrm{v}$ sedimentu, které navíc pronikaly do větších hloubek sedimentu a ke srážení rozpuštěného Fe a současně $P$ docházelo ještě efektivněji. Z průběhu koncentrací Fe na počátku inkubací a dále $v$ anoxické variantě by ovšem mělo docházet k uvolňování Fe do anoxické vody. Tento proces však nebyl zaznamenán při monitoringu složení vody nad sedimentem a byl způsoben srážením redukované formy Fe do formy sulfidů FeS na povrchu sedimentu díky souběžné redukci síranů.

Obsah $\mathrm{P} v$ pórové vodě jednotlivých vrstev Ize rozdělit do dvou částí i) $\mathrm{H}_{2} \mathrm{O}$ frakce (modrá složka) odpovídá $\mathrm{P}$, který se při přechodu do oxické vody díky disturbancím sedimentu (hydraulická resuspenze, aktivita ryb a další) není schopen srazit s rychle oxidovaným Fe pocházejícím ze stejné pórové vody a vytvorit nové částice a ii) $\mathrm{HNO}_{3}$ frakce (oranžová část), která je $s$ tímto rozpuštěným Fe potencionálně srazitelná v oxických podmínkách. $\mathrm{H}_{2} \mathrm{O}$ část $\mathrm{P}$ pórové vody je tedy $v$ prípadě resuspenze okamžitě $v$ rozpuštěné formě dostupná pro organismy ve vodním sloupci a představuje největší riziko z celkového obsahu $P$ $v$ sedimentu. Pokud by došlo k resuspenzi sedimentu do hloubky $3 \mathrm{~cm}$ u sedimentu na počátku inkubace, uvolnilo by se v průměru 90 mg P z jednoho čtverečního metru sedimentu, z čehož $18 \mathrm{mg}$ by se $v$ prípadě oxické vody nebylo schopno srazit s Fe, a stalo se tak okamžitě dostupným.

\section{Formy $\mathrm{P}$ v sedimentu a změny složení částic}

Sediment obsahoval na počátku inkubačního pokusu $v$ horních $9 \mathrm{~cm}$ celkem $35 \mathrm{~g} \cdot \mathrm{m}^{-2} \mathrm{P}$. Celkové množství různých forem $\mathrm{P}$ a Fe stanovovaných frakcionační analýzou, stejně jako jejich procentuální zastoupení v různých vrstvách je zobrazeno na obr. 5. Průměrně $29 \pm 3$ \% P bylo vázáno ve vysoce redukčně labilních

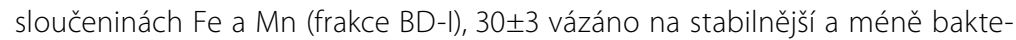

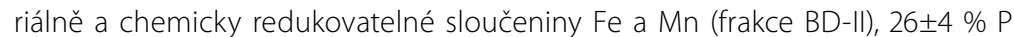
vázaného na amorfní (hydr)oxidy Al a v organických formách (frakce $\mathrm{NaOH}-\mathrm{l}$ ), $11 \pm 2 \%$ ve stabilních organických formách a krystalických oxidech Al (frakce $\mathrm{NaOH}-\mathrm{II}), 4 \pm 1$ \% P ve sloučeninách labilních v nízkých hodnotách $\mathrm{pH}$. Fosfor je $\checkmark$ tomto typu sedimentu převážně vázán v železitých (hydr)oxidech, jejich největší zastoupení je pak ve svrchních 3 centimetrech.

Změny, které se odehrály během sledovaného období, byly nejvýznamnější ve svrchních $3 \mathrm{~cm}$ sedimentu, a byly téměř výhradně způsobeny změnami množství $P$ vázaného na redox labilní (hydr)oxidy Fe a následně Mn, který měl ovšem menší význam vzhledem k jeho malému množství v sedimentu (obr. 6). Uvolňovaný P ze sedimentu pod anoxickým vodním sloupcem byl způsoben rozpouštěním snadno dostupných (hydr)oxidů Fe, které slouží jako terminální akceptor elektronů při mikrobiálním rozkladu organických látek, a na nich vázaného $P$ (frakce BD-I). Pokles jejich množství byl patrný zejména v nejsvrchnější vrstvě 0-1 cm (pokles P o $48 \%$, pokles Fe o 38 \%, viz tabulka 2). Jak bylo ukázáno dřive, Fe se ze sedimentu $v$ anoxické variantě neuvolňovalo, nebot̉ docházelo ke srážení FeS díky silným anoxickým podmínkám a redukci síranů (stanoveno jako AVS - acid volatile sulfur a přepočitáno s molárním poměrem S: Fe 1 : 1). Naopak v obou oxických variantách došlo k nabohacení $P \vee B D-I$ frakcích, 

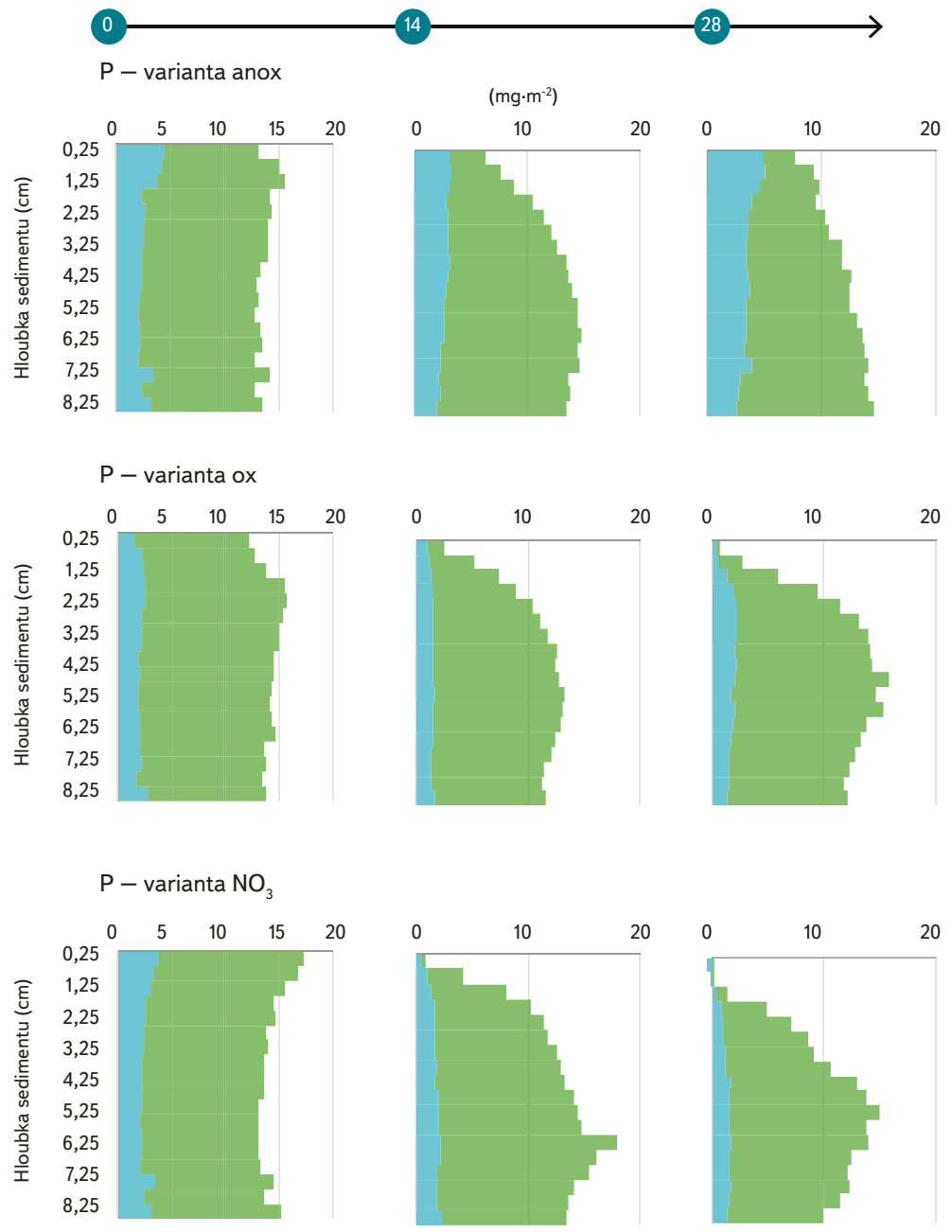
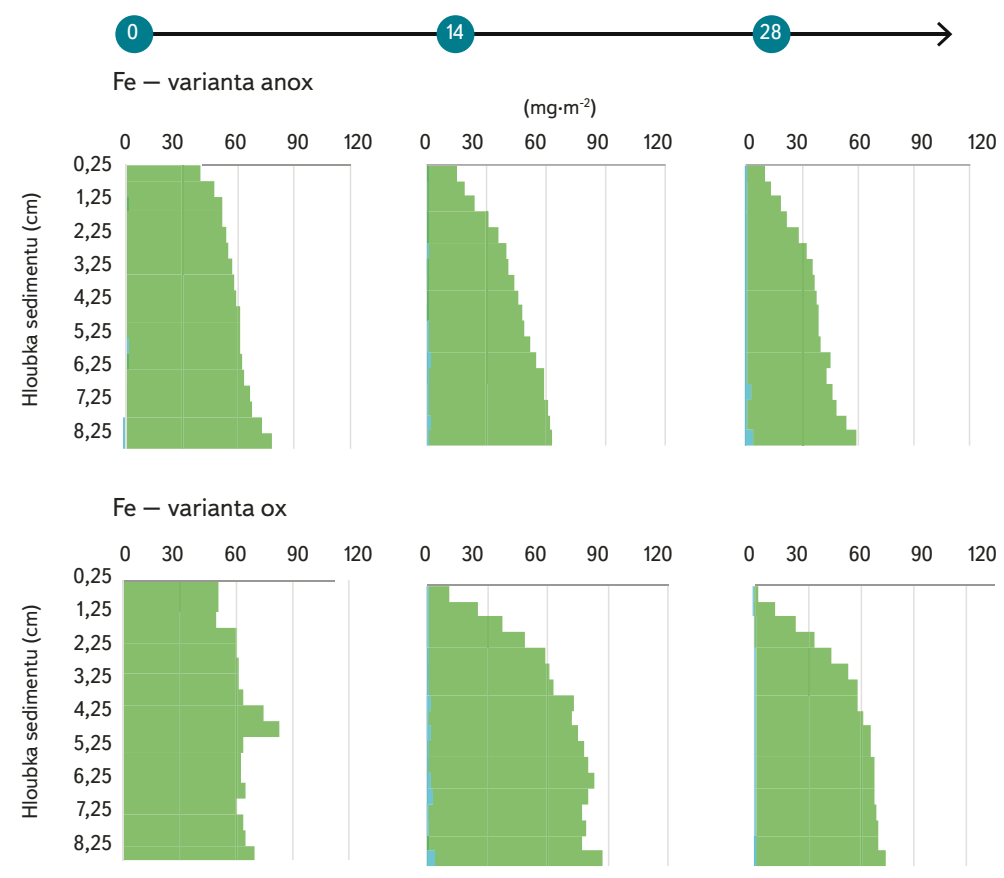

$\mathrm{H}_{2} \mathrm{O}$

\section{$\mathrm{HNO}_{3}$}

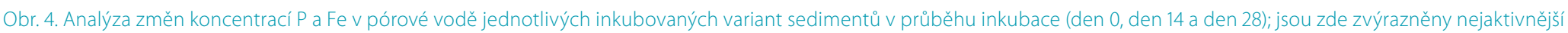
první $3 \mathrm{~cm}$ sedimentu vykazující změny $\vee$ koncentracích

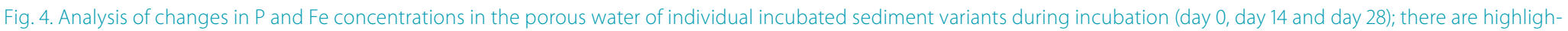
ted the most active first $3 \mathrm{~cm}$ of sediment exhibiting changes in concentrations

a to o desítky procent (obr. 6, tabulka 2). Tento efekt byl způsoben jednak vysrážením rozpuštěného $P$ a Fe $z$ pórové vody a pravděpodobně také díky přeměně pưvodních hưre dostupných (hydr)oxidů Fe. Zatímco při dostupnosti rozpuštěného $\mathrm{O}_{2}$ a $\mathrm{NO}_{3}$ - docházelo k nabohacení množství $\mathrm{P}$ a Fe v BD-I frakci, došlo k ochuzení $P$ a částečně Fe $v$ hưre dostupných formách (BD-II). Tento fakt byl zapř́činěn bud' oxidací a uvolněním organických látek nasorbovaných na povrchu železitých (hydr)oxidů nebo oxidací redukovaných Fell iontů taktéž na površích těchto sloučenin. Oba mechanismy v sedimentech zneprístupňují bakteriím prenášet elektrony na Fe ${ }^{\| l !}$ (hydr)oxidy [6, 7]. V BD-II frakci jsou navíc extrahovány krystalické (hydr)oxidy Fe, které mají nižší sorpční schopnosti pro P. Tyto minerály tak zůstaly beze změny, což naznačují zvýšené molární poměry Fe/P $\vee$ této frakci v obou oxických variantách (tabulka 2).

\section{Potencionální význam $\mathrm{P}$ ze sedimentu pro př́tokovou část nádrže}

Přes veškerou snahu se při inkubaci přiblížit podmínkám v nádrži, včetně použití nejlepších dostupných postupů, bude vždy obtížné extrapolovat výsledky do většího měřítka. I presto se níže pokusíme o vyjádření vztahu mezi naměřenými výsledky a situací v nádrži.

Na základě předchozího monitoringu Ize předpokládat:

- Při ploše sedimentů s oxicko-anoxickým režimem $200000 \mathrm{~m}^{2}$, průměrnou hloubkou této části nádrže 1,5 m je objem vody nad plochou: 300000 m³, pak, při koncentraci rozpuštěného $P 0,05 \mathrm{mg} \cdot \cdot^{-1}$ je ve stanoveném objemu obsaženo $15000 \mathrm{~g}$ P.

— Při uvolňování $12,4 \mathrm{mg} \cdot \mathrm{m}^{-2} \cdot \mathrm{d}^{-1}$ je denně do definovaného objemu uvolněno 2500 g P, ti. $17 \%$ dostupného $P$ ve vodním sloupci. 

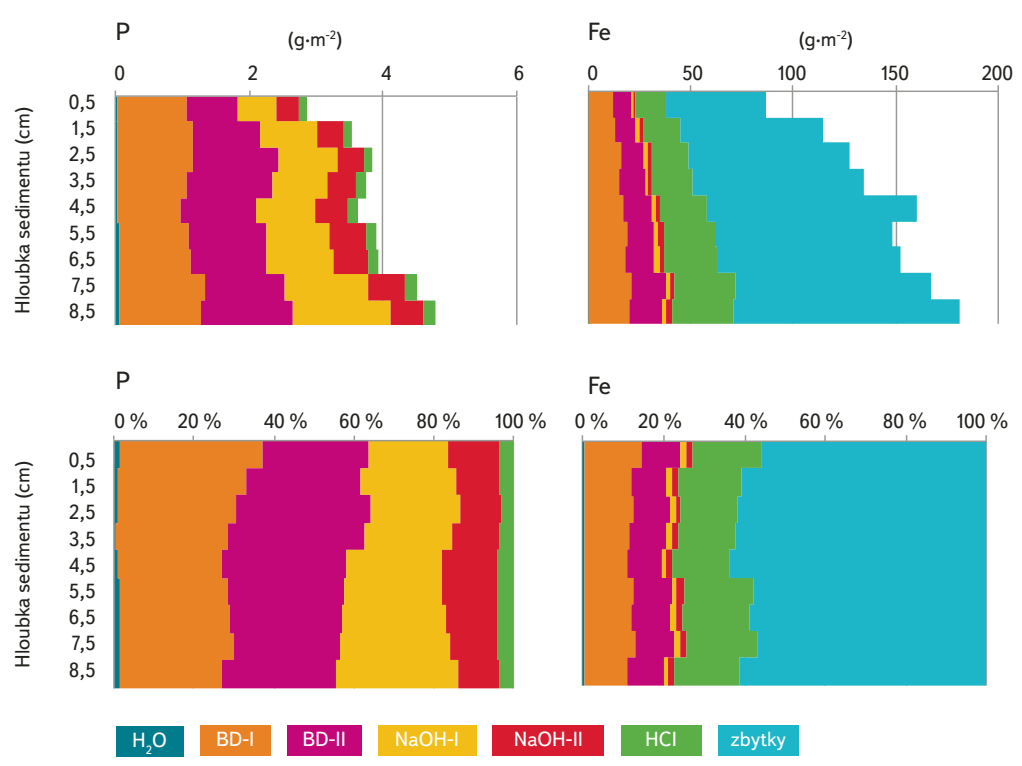

Obr. 5. Obsah jednotlivých forem P a Fe a jejich procentuálního zastoupení v sedimentu stanovených pomocí frakcionační analýzy

Fig. 5. Content of individual $\mathrm{P}$ and Fe forms and their percentages in sediment determined by fractionation analysis
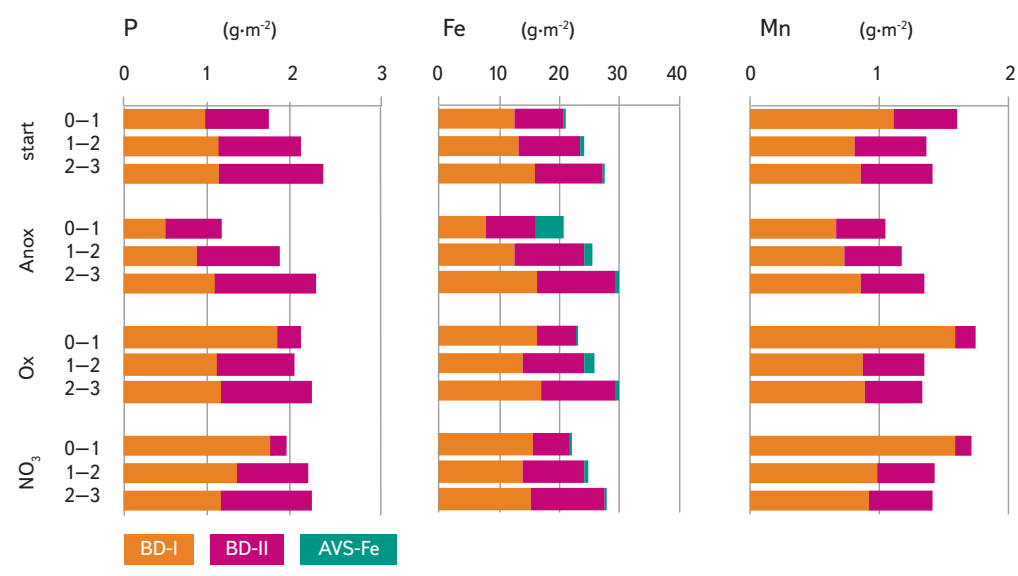

Obr. 6. Obsah P, Fe a Mn ve svrchních $3 \mathrm{~cm}$ sedimentu extrahovaných ve frakcích BD-I a BD-II preded inkubací (varianta start) a po inkubacích jednotlivých variant (varianta anox, ox a $\mathrm{NO}_{3}$ ); AVS-Fe bylo stanoveno jako sulfidická síra přepočítána na Fe $\checkmark$ molárním poměru 1:

Fig. 6. P, Fe and Mn content in the upper $3 \mathrm{~cm}$ sediment extracted in BD-I and BD-II fractions prior to incubation (start option) and after incubation of individual variants (anox, ox and $\mathrm{NO}_{3}$ variant); AVS-Fe was determined as sulphide sulfur converted to Fe in a molar ratio of $1: 1$

- Ve svrchní vrstvě 0-3cm sedimentu, za anoxických podmínek, je obsaženo $20 \mathrm{mg} \cdot \mathrm{m}^{-2}$ rozpuštěného a nesrazitelného $\mathrm{P}\left(\mathrm{H}_{2} \mathrm{O}\right.$ frakce). Při uvažované ploše $200000 \mathrm{~m}^{2}$ se toto množství rovná $12000 \mathrm{~g}$ P. Toto množství představuje 80 \% dostupného P prítomného ve vodním sloupci nad danou lokalitou. Při potencionální resuspenzi sedimentu by se tedy uvolnilo obrovské množství

- Za prítomnosti kyslíku a současně $\mathrm{NO}_{3}{ }^{-}$ve vodním sloupci (varianta $\mathrm{NO}_{3}$ ) je obsah tohoto nejrizikovějšího $P$ ve vrstvě $0-3 \mathrm{~cm}$ pouze $3 \mathrm{mg} \cdot \mathrm{m}^{-2} \mathrm{P}$. V definované ploše je toto množství rovno $1800 \mathrm{~g}$ P, tj. $15 \%$ dostupného P ve vodním sloupci. Sedimenty v takovémto stavu jsou při resuspenzi daleko méně problematické.

Tabulka 2. Procentuálnízměny P a Fe během inkubacev BD-I a BD-II frakcích vưči hodnotám pred počátkem inkubacía molárnípoměry Fe/Pv jednotlivých frakcích a vrstvách sedimentů Table 2. Percent changes of $P$ and Fe during incubation in BD-I and BD-II fractions relative to pre-incubation and molar Fe/P ratios in individual fractions and sediment layers

\begin{tabular}{|c|c|c|c|c|c|c|c|}
\hline & \multirow[t]{3}{*}{ Hloubka $(\mathrm{cm})$} & \multicolumn{4}{|c|}{ Změna obsahu látek ve frakcích po inkubacích (\%) } & \multicolumn{2}{|c|}{ Molární poměry } \\
\hline & & \multicolumn{2}{|l|}{ P } & \multicolumn{2}{|l|}{$\mathrm{Fe}$} & \multicolumn{2}{|l|}{$\mathrm{Fe} / \mathrm{P}$} \\
\hline & & BD-I & BD-II & BD-I & BD-II & BD-I & BD-\|I \\
\hline \multirow[t]{3}{*}{ start } & $0-1$ & & & & & 7 & 6 \\
\hline & $1-2$ & & & & & 7 & 6 \\
\hline & $2-3$ & & & & & 8 & 5 \\
\hline \multirow[t]{3}{*}{ Anox } & $0-1$ & -48 & -12 & -38 & 0 & 8 & 7 \\
\hline & $1-2$ & -23 & 1 & -6 & 13 & 8 & 6 \\
\hline & $2-3$ & -4 & -2 & 2 & 16 & 8 & 6 \\
\hline \multirow[t]{3}{*}{ Ox } & $0-1$ & 83 & -64 & 30 & -21 & 5 & 14 \\
\hline & $1-2$ & 0 & -8 & 3 & 2 & 7 & 6 \\
\hline & $2-3$ & 2 & -14 & 5 & 10 & 8 & 6 \\
\hline \multirow[t]{3}{*}{$\mathrm{NO}_{3}$} & $0-1$ & 75 & -74 & 25 & -27 & 5 & 18 \\
\hline & $1-2$ & 21 & -16 & 3 & 1 & 6 & 7 \\
\hline & $2-3$ & 3 & -12 & -6 & 11 & 7 & 6 \\
\hline
\end{tabular}




\section{ZÁVĚR}

Sedimenty z prítokových částí nádrží mají velký vliv na trofický stav nádrží vzhledem $\mathrm{k}$ jejich blízkému kontaktu s epilimnetickou vodou. Uvolňovaný $\mathrm{P}$ ze sedimentů tak snadno přechází do produkční zóny fytoplanktonu ve vodním sloupci a zvyšuje dostupnost živin i v hlubších již stratifikovaných částech nádrže. Sediment z nádrže Vranov je značně závislý na dostupnosti rozpuštěného $\mathrm{O}_{2}$ a také $\mathrm{NO}_{3}$; které zabraňují při jejich dostupnosti uvolňování $\mathrm{P}$ ze sedimentů. $\vee$ prípadě jejich nedostatku jsou využívány (hydr)oxidy Mn a zejména pak Fe při mikrobiální mineralizaci nasedimentovaného organického materiálu. Rozpouštění těchto (hydr)oxidů s nasorbovaným P pak vede k uvolňování velkého množství P ze sedimentu. Rychlost uvolňování $P$ za anoxických podmínek odpovídala $12,4 \mathrm{mg} P$ na $\mathrm{m}^{2}$ za den. Toto množství tak výrazně přispívá $\mathrm{k}$ dostupnosti živin $v$ nádrži. Za prítomnosti rozpuštěného $\mathrm{O}_{2} \mathrm{a} /$ nebo $\mathrm{NO}_{3}{ }^{-}$jsou naopak tyto (hydr)oxidy schopné $P$ zadržovat a kumulovat se $v$ horních vrstvách sedimentu. Toto zadržení však není trvalé a při změně nestabilních oxických podmínek ve vodě nad sedimentem nebo překrytí novým organickým materiálem může docházet $k$ jejich uvolnění. Fosfor obsažený v pórové vodě se také stane rychle dostupným pro vodní sloupec, pokud dojde k narušení povrchu sedimentu at již zvýšenými průtoky a resuspenzí, či narušením způsobeným aktivitou ryb.

\section{Poděkování}

Tato práce vznikla za podpory Technologické Agentury České Republiky (projekt č. TA04021342) a MŠMT (projekt č. LM2015075 a EF16_013/0001782 - SoWa Ecosystems Research).

Příspěvek byl publikován ve sborníku konference Vodní nádrže 2017, ISBN 978-80-905368-5-2.

\section{Literatura}

[1] KOSOUR, D., DURAS, J. a HANÁK, R. VN Vranov - situace a možnosti řešení jakosti vody. In: Kosour, Dušan et al., ed. Vodní nádrže 2015: 6.-7. ríinna 2015, Brno, Česká republika. Brno: Povodí Moravy, s. p., 2015. ISBN 978-80-260-8726-7.

[2] WETZEL, R.G. Limnology: lake and river ecosystems, 3rd ed. Academia Press, San Diego, 2001.

[3] BOROVEC, J., JAN, J. a JAROLÍMOVÁ, Z. Využití gelových minipeeperů při sledování složení pórové vody $\mathrm{V}$ sedimentech. Zborník prednášok $z \mathrm{~V}$. konferencie $s$ medzinárodnou účastou Sedimenty vodných tokov a nádrží, 2009. ISBN 978-80-89062-61-4.

[4] JAN, J., BOROVEC, J. a HUBÁČEK, T. Co umíme ríci o sedimentech, aneb hodnocení sedimentů v nádržích ve vztahu k eutrofizaci. In: Kosour, Dušan et al., ed. Vodní nádrže 2015: 6.-7. října 2015, Brno Česká republika. Brno: Povodí Moravy, s. p., 2015. ISBN 978-80-260-8726-7.

[5] JAN, J., BOROVEC, J., KOPÁČEK, J., and HEJZLAR, J. Assessment of phosphorus associated with Fe and Al (hydr)oxides in sediments and soils. 2015. J Soils Sediments 15: 1620-1629.

[6] RODEN, E.E. and URRUTIA, M.M. Ferrous iron removal promotes microbial reduction of crystalline iron (III) oxides. 1999. Environ Sci Technol. 33: 1847-1853.

[7] EUSTERHUES, K., HÄDRICH, A., and NEIDHARDT, J., et al. Reduction of ferrihydrite with adsorbed and coprecipitated organic matter: Microbial reduction by Geobacter bremensis vs. abiotic reduction by Na-dithionite. 2014. Biogeosciences 11: 4953-4966.

\section{Autoři}

Mgr. Jiří Jan, Ph.D.

凶jiri.jan@bc.cas.cz

RNDr. Jakub Borovec, Ph.D.

凶jakub.borovec@bc.cas.cz

MSc. Daniel Petráš

凶daniel.petras@bc.cas.cz

MSc. Nana Osafo

凶nana.osafo@bc.cas.cz

Ing. Iva Tomková

凶iva.tomkova@bc.cas.cz

Ing. Tomáš Hubáček, Ph.D.

凶tomas.hubacek@bc.cas.cz

Biologické centrum AV ČR, v. v. i., Výzkumná infrastruktura SoWa

Příspěvek prošel lektorským řízením.

\section{THE IMPACT OF OXYGEN AND NITRATES AVAILABILITY ON PHOSPHORUS CYCLE IN SEDIMENTS - AN EXAMPLE OF THE VRANOV RESERVOIR}

\section{JAN, J.; BOROVEC, J.; PETRAS, D.; OSAFO, N.; TOMKOVA, I.; HUBACEK. T.}

Biology Centre CAS, SoWa Research Infrastructure

Keywords: sediment - oxygen - phosphorus - iron - eutrophication

This study focus on phosphorus (P) release from sediment of inflow part of Vranov reservoir under different availability of terminal electron acceptors, mainly dissolved $\mathrm{O}_{2}$ and $\mathrm{NO}_{3}$. The inflow parts of eutrophic reservoirs typically exhibit exacerbated rates of primary production, with concomitant increase in organic matter sedimentation. Its microbial remineralization leads to the consumption of electron acceptors, shifting their availability depending on water column mixing. To understand the cycling of $P$ in sediments, sediment cores were incubated for five weeks in three parallel variations that simulated: i) anoxia with depleted $\mathrm{NO}_{3}$; ii) $\mathrm{O}_{2}$ saturated water column and iii) $\mathrm{O}_{2}$ saturated water column in the presence of high concentrations of $\mathrm{NO}_{3}$. Evaluating the release of $\mathrm{P}$ and the impact of Iron (Fe) and its metabolism in sediment under the different conditions, water above the sediments was monitored, porewater composition and different $\mathrm{P}$ fractions in the sediment were analysed. 